\title{
Potrzeba etyki i religii w odniesieniu do filozofii*
}

\section{Odczyt pierwszy}

\author{
Wprowadzenie
}

Żyjemy w epoce, w której ludzie szczycą się, że są wykształceni. Co znaczy słowo „kształcenie”? Tyle co uszlachetnienie? Czy nazwiemy wykształconą epokę, w której ludzie uważają, że prowadzą piękniejsze i godniejsze życie niż we wcześniejszych okresach rozwoju gatunku ludzkiego? Jednak nie tylko starcy... wahaja się, aby właśnie naszemu sposobowi myślenia i życia przyznać chwałę, która wynosi dzisiejsze stosunki tak prywatne, jak i publiczne ponad historię. Również bezstronni krytycy wskazują na oznaki zmniejszającej się doskonałości. Niewątpliwie w naszych czasach uformowała się sztuka, powstał przemysł, mnożą się wynalazki i produkty na rynkach ułatwiające życie codzienne i duchowe. Ale różne sposoby myślenia mogą przyczynić się do rozwoju lub upadku człowieka. Dziś stawia się obok siebie oszustwo i wierność, wiedzę oraz zwątpienie, a nawet przemoc i koligacje...

* Tytuł oryginału: Über das Bedürfnis der Sittenlehre und Religion in ihrem Verhältnis zur Philosophie. Przethumaczono na podstawie: Johann Friedrich Herbarts Sämmtliche Werke in chronologischer Reihenfolge, t. 1, red. K. Kehrbach, Verlag von Beyer 1887, s. 116-126.

Jest to zbiór czterech odczytów wygłoszonych przez Herbarta w Bremie w 1800 roku, po powrocie ze Szwajcarii. Do miasta przybył on na zaproszenie przyjaciela ze studiów w Jenie - Johanna Smidta (1773-1857) i od 1800 do 1802 przygotowywał się do rozpoczęcia pracy naukowej. W tym okresie w Bremie toczyły się spory dotyczące potrzeby oddolnej reformy edukacji. Ważną rolę w kształtowaniu opinii publicznej odgrywało towarzystwo społeczne o nazwie „Muzeum”, które powstało w 1776 roku w celu wspierania rozwoju życia duchowego mieszkańców portowego miasta nad Wezera. Pierwszy odczyt pt. „Czy współczesne czasy są lepsze niż poprzednie?” Herbart wygłosił 3 listopada 1800 roku. 
Czy może kogokolwiek jeszcze dziwić, że kolorowym zwyczajom odpowiada równie barwna etyka? Pojęcia postępują za rzeczami, słowa za przyzwyczajeniami. Język ulega wygładzeniu...

Młodemu człowiekowi, który szuka wykształcenia, nie zabraknie ani ludzi, ani tym bardziej książek, które zaoferują mu kierownictwo w świecie.

Z pewnością na początku będzie się on cieszył z bogactwa dobrych okazji. Jednak ze względu na to, że będzie się starał wykorzystać je wszystkie naraz, ujdąjego uwadze - być może nawet przez dłuższy czas - ukrywające się pod tym wszystkim sprzeczności i przeciwieństwa, które z uniżoną miną chcą zdobyć jego zaufanie. Znałem kiedyś wrażliwe osoby, które niemalże z miłosnym oddaniem zajmowały się Goethem, Jacobim ${ }^{1}$ i Fichtem, najnowszą filozofią i wiedzą teologiczną. Nie zważały one na to, gdzie jedna teoria styka się z drugą ani się nie obawiały, że któraś z nich zostanie zepsuta przez inną, ani też - co jest rzeczą najważniejszą - nie interesowała ich konsekwencja i sprawdzalność przyjmowanych teorii.

Jeżeli jednak ktoś posiada w sobie choćby zalążek charakteru, ten musi przeciwstawić się temu zgubnemu wpływowi naszej kolorowo wykształconej epoki. Jego natura spontanicznie zaprotestuje przeciwko takiemu „naginaniu” i będzie on w nieprzyjemny sposób czuł się pobudzony przez to, co jest zbyt wysokie i wysublimowane. Będzie starał się uchwycić we współczesnej kulturze sprzeczności, aby przez to usprawiedliwić swoje ogóle zwątpienie względem wartości jakiegokolwiek kształcenia, i albo będzie chełpił się swoją ociężałościq wobec wszystkiego, co wyższe, albo pozostawi wolną przestrzeń dla swoich właściwości, które jego zdaniem są tak samo dobre, jak u innych ludzi.

Przykładów drugiego sposobu zachowania jest znacznie więcej niż pierwszego. Istnieje bowiem wielu ludzi, którzy sadzą, że wolno im robić wszystko, na co mają ochotę, jeśli tylko należycie spełnili swoje obowiązki zawodowe i to, co jest z tym związane, a po wykonanej pracy chcą się zabawić w taki sposób, że przynosi to korzyść zarówno obiegowi pieniądza, jak i przemysłowi rozrywkowemu.

Obojętność wobec zła i kult czasowości może wynikać u nich ze sprzecznej natury świata duchowego... Ale gdyby nawet nieczułość i obojętność wobec piękna i dobra powstawały w tak naturalny sposób, gdyby obecna sytuacja polityczna i stan literatury tak bardzo im sprzyjały, to mimo wszystko istota ludzkiej natury jest $w$ swojej głębi inna $i$ jest ona niezmienna...

A zatem, moi panowie, zakładam, że nie zapuściła w was jeszcze korzeni nieufność wobec tego, co ogólnie określa się mianem kształcenia i że nosicie w sobie nie tylko wszechstronne zdolności do przyjęcia lepszego lub gorszego jego rodzaju, lecz odczuwacie potrzebę oddzielenia jednego od drugiego. W takich sytuacjach człowiek sam dla siebie staje się miarą. Bez niej nie zrozumie-

${ }^{1}$ Friedrich Heinrich Jacobi (1743-1819) - niemiecki filozof, prawnik i pisarz. Był przedstawicielem filozofii uczuć. Należał do pierwszych krytyków Rewolucji Francuskiej, którą uważał za reakcję polityczną na nihilizm filozofów epoki. 
libyśmy sensu pojęcia dobra, ani nie zdobyli szacunku wobec obowiązku, ani podziwu dla cnoty.

Godne podziwu są wszelkie działania na rzecz praw i dobra ludzkości. Prześledzenie motywów takich zachowań pomogłoby postępować w sposób podobny.

Człowiek nie znajduje upodobania w próżnych uciechach. Bezmyślną realizację przyjemności utrudnia mu „wewnętrzny widz”. Nigdzie nie schronimy się przed jego oglądem. Aby w takich chwilach odczuwać radość, należałoby przekłamać samych siebie.

Należy ubolewać, że to wewnętrzne świadectwo słyszy się tylko przy pewnej okazji; człowiek rozumie te komunikaty dopiero po zakończeniu działania. Przedtem działa popęd, który raz utożsamiamy ze sobą, a raz z czymś obcym wobec nas. Nazywamy go wówczas odurzeniem i jest nam przykro z powodu naszych zachowań.

Człowiek nie chce rozpoznawać samego siebie. W chwili namiętności uważa rozum za obcego wichrzyciela. Gdy się zastanowi, nie chce przyznać, że namiętność jest elementem jego istotowości. W ten sposób może się wydawać, że jesteśmy złożeni z części zupełnie do siebie niepasujących i nasze prawdziwe ,ja" jest snem.

Kto myślący mógłby znieść taką myśl? Niemniej jesteśmy zmuszeni do tego tak długo, jak długo afirmujemy siebie takimi, jakimi jesteśmy. Aby stworzyć dobry charakter, musimy zapoczątkować w nas nowe istnienie. Trzeba począć siebie samego od nowa dzięki postanowieniu, że muszę tworzyć siebie - każdy musi sam siebie ustanowić, ale nie takim, jakim jest, lecz takim, jakim chciałby być.

$\mathrm{Z}$ pewnością rozpoznajecie, moi panowie, że w tych stwierdzeniach zawierają się sformułowania współczesnej teologii i filozofii. Tak jest w istocie, ale już we wcześniejszych czasach różni ludzie wyrażali swoje głębokie przekonanie, że niemożliwe jest dotarcie do samego siebie. Mówiąc obrazowo, człowiek jest tylko pielgrzymem do świątyni obowiązku. Gdy do niej dotrze, będzie mógł ogarnąć swoją najprawdziwszą istotę i w niej dopiero osiągnie wewnętrzną radość i trwały pokój z samym sobą.

Zgodnie z tym sposobem patrzenia, najwyższe prawo, mądrość i dobro mają to samo źródło. W ludziach mądrych uwidacznia się posłuszeństwo, panowanie, wyrzeczenie i zaspokojenie.

Tylko gdzie jest ów mędrzec? Kto nim jest? Kto może nim się stać? Kto jest w stanie wypełnić najwyższe prawo i osiąnąć najwyższe dobro?

Zazwyczaj te małoduszne i trwożliwe pytania odpychająumysł, który ledwo co zdołał się podnieść, i gaszą jego zapał. Albowiem kto w ten sposób pyta, ten nie ma zamiaru szukać pouczenia w sprawach ludzkiego ducha. Ludzi tak rozumujących nie powinno się zmuszać do zgłębiania metafizyki ani psychologii. Do tego trzeba dużo siły etycznej, a oni uznają jedynie działania rutynowe i łatwo się zniechęcają trudnościami. Charakterystyczną cechą owych ludzi jest to, że nie chcą oni uznać żadnej reguły działania, której jeszcze nie dowiedziono. $\mathrm{Z}$ tego rodzi się rutyniarstwo. 
Tymczasem początkiem wszystkich sztuk są odważne czyny. Tak było z farmacją, polityką i strategią. Niczego by nie osiągnięto bez podejmowania prób.

... Małoduszność jest podobna do zarozumiałości. Słabość jednej powoduje ten sam stan drugiej. Obie panują u tych, którzy nie chcą działać, dopóki nie widzą przed sobą jasno możliwości zrealizowania swoich zamierzeń. Niewątpliwie człowiek rozsądny nigdy nie będzie chciał, aby jego działania dokonywały się na chybił trafił, ale tylko ten, kto coś robi, może czegoś dokonać...

Tutaj znajduje się ważny punkt zależności między moralnością a religią. Od dawna wszystkie narody szukały w wierze odwagi. Bez niej brakowało trwałej zasady do prowadzenia jakiegokolwiek wytrwałego działania. Religia musiała użyczać jej ludziom. Najpierw działano, a później rozwijano wiarę, która by odpowiadała czynowi.

Ową zmienność myślenia religijnego i nastawienie moralne widać wyraźnie w systemach filozoficznych Spinozy, Fichtego, Platona, a także Epikura.

Zastanówmy się, czym przez tę zależność stają się religia i etyka oraz czy jest to korzystna przemiana. Nawet najlepsi ludzie łączą obie te dziedziny.

$\mathrm{Na}$ zakończenie kilka myśli i uwag dotyczących przedmiotu następnego naszego odczytu. Przypomnijmy sobie pierwotne upodobanie i nieupodobanie, które powstają w nas samych, to znaczy: ów jedyny trwały punkt, który w takim samym stopniu jest niewzruszony i nietknięty przez wątpliwości spekulacyjne, jak i wszelką zmianę naszego nastroju, skłonności, pożądań i namiętności.

\section{Odczyt drugi}

Życie musi być ruchem pełnym konsekwencji, składającym się z aktywności i odpoczynku.

Potrzeby zmuszają człowieka do działania, szlachetną jednostkę zaś skłaniają do tego zmysł sztuki i poczucie etyczne. Podmiot nie powinien zużywać na nie wszystkich sił. Musi pozostawić sobie chwile wyciszenia, bezczynności i refleksji. Jeżeli człowiek odda się całkowicie działaniu, to nie pozna samego siebie. Bez wewnętrznego spokoju niczego nie można uczynić zgodnie z planem. Doskonałe połączenie obu tych elementów jest niemożliwe, ponieważ uwaga człowieka skupia się na okolicznościach, przez co zmienia się jego wnętrze. Aby powrócić do pierwotnego stanu, potrzeba wielu chwil zastanowienia.

W tym stanie człowiek dostrzega, a przy tym kontroluje, siebie i świat dookoła. Człowiek moralny w takich chwilach z zadowoleniem rozmyśla nad sobą. Szczęśliwe są także jednostki religijne, które wierzą, że nic nie zmusza ich do niechęci wobec świata, natomiast krytykantom i sceptykom brakować będzie pogody ducha i pozytywnej siły...

Mamy tutaj zebrane razem wszystko, co może nam wyjaśnić potrzebę tak etyki, jak i religii. Zadaniem tej pierwszej jest określenie nas w działaniu; od niej musi się rozpoczynać formułowanie naszych postanowień. 
Religia musi rozpogadzać nasze spojrzenie na świat, w którego centrum się znajdujemy; ma nas chronić, abyśmy nie uważali siebie samych za obcych, którzy znaleźli się we wrogiej okolicy.

Zapytajmy teraz, czy religia nie ma żadnego wpływu na nasze działanie? Łatwo odpowiedzieć na to pytanie, gdyż działanie wydaje się całkowicie określone przez zasady etyki. Otóż, etyka określa naszą wolę i wskazuje nam cele w życiu, jednak pozostawia też wątpliwości co do ich osiągnięcia... Stąd do realizacji małych spraw potrzebujemy mądrości, a do spełniania wielkich - religii.

Mądrość bada szczegółowo okoliczności i docieka, czy nadszedł właściwy czas na działanie. Jeżeli nie, to każe nam czekać na lepszą okazję... Jednak krąg widzenia mądrości jest ograniczony. Trzeba go poszerzyć o szlachetną ufność, która wspiera się na oznakach sprzyjającej nam natury. Jak przyjaciel, musi podnosić nas na duchu w chwilach odpoczynku i umacniać nasze poczucie dobra i piękna... Wpierw jednak trzeba zasłużyć na takiego przyjaciela, aby później móc przeżywać szczęście z jego posiadania. Tak więc należy uszlachetnić serce, aby duch mógł sięgnąć myślą boskości.

Trudno spomiędzy ludzkich spraw wybrać lepszą od religii, która tak bardzo upodabnia się do przyjaźni. Przyjaźń i religia wymagają od jednostki uspokojenia. Opierają się na szczerym i nieegoistycznym uczuciu, a przy tym wiążą się z wiernością, wiarą i przywiązaniem. Nie walczą ze sceptycyzmem przez apodyktyczność. Trzeba je poczuć i zapamiętać. Obie mają źródło w zaufaniu podobnym do tego uczucia, które jest podstawą istnień duchowych ${ }^{2}$. Pozwalają nam cieszyć się dobrocią naszej woli i powodzeniem w działaniu. Nigdy nie pozbawiajmy siebie samych zażyłości wynikającej z przyjaźni oraz okazji do świętowania religii!

\section{Odczyt trzeci}

Etyka dotyczy działania, religia zaś spoczynku. Tak więc to nie sumienie należy wzmacniać, ale mądrość opartą na zaufaniu realizowanym w przestrzeni Absolutu, które chroni nas przed wątpliwościami i weryfikuje chcenia. Dokonujemy wyboru odpowiednich celów i środków w oparciu o wiedzę i władzę sądzenia.

Warto też się zastanowić, czy można kształtować w sobie etykę na czas odpoczynku, a religię w celu działania. W stanie bierności odczuwamy bodźce środowiska bez wyrażania pragnień zapoczątkowujących działanie, etyczność zatem musiałaby wiązać się z odczuciami, których nie potrafimy się wyuczyć ani nimi kierować. Powinna przynosić satysfakcję tak jak teorie hedonistyczne, które dążą do usunięcia trosk i zachowania dobrego samopoczucia. W tym wypadku

${ }^{2}$ Powyższe zdanie świadczy o realistycznej postawie poznawczej Herbarta, która przejawiała się w klarownej interpretacji przedmiotu jako podstawie myślenia filozoficznego i pedagogicznego. W późniejszym czasie oldenburczyk określał swój system filozoficzny mianem „surowego realizmu". 
to odczucie, a nie chcenie jest przedmiotem etyki. Niektóre religie podzielają ten pogląd, zakładają bowiem, że bóstwa nie martwią się o ludzi...

Teoria przyjemności opiera się na przeświadczeniach, dlatego nie jest przeznaczona dla osób silnych i aktywnych, które wolą bez refleksji etycznych oddawać się kultowi działania. Pragnienie jest dla nich najważniejsze, a religia powinna udzielić im wsparcia. Ludzie ci robią, co chcą i nie mają czasu na poszukiwanie prawdziwej wiary. Ustanawiają idee bóstwa dla domu, rodziny, kraju, narodu, a nawet dla własnego szczęścia. Są egoistami. Ci mniej silni stworzą religię strachu i będą postępować tak, aby nie łamać przepisów nadprzyrodzonej mocy przez siebie konstytuowanej. Aktywniejsi i wyedukowani będą drwić z obrządków wiary, myślenia teoretycznego oraz namiętności. Opowiedzą się za stanowiskami filozofów uważających człowieka za ogniwo współtworzące pojęcia o świecie. Sami ustanawiają najwyższe wartości i systemy powiązań, które tylko na pozór definiują rzeczywistość.

Do tej ,religii silnych” podobne są różne stanowiska filozoficzne, które pochodzą od ludzi uważających się za kompetentnych w „królestwie pojęć”. Wielu z nich dąży do zdobycia władzy nad pojęciowaniem, ale rzadko im się to udaje. W tym wypadku nawet wiedza matematyczna pozostaje niedoskonała pod względem formy. Przypomina to nasze panowanie nad ruchem ciała, które odbywa się zwykle podświadomie.

Pojęcia nieempiryczne utrudniają swój ogląd przez zaciemnianie przedmiotu, jednak każde podporządkowanie definicji warte jest wysiłku. Najważniejsze wciąż pozostaje panowanie nad sobą.

Kończąc, można stwierdzić, że tylko jedna forma władzy wznosi się ponad panowanie w „królestwie pojęć”, a mianowicie panowanie nad sobą samym.

\section{Odczyt czwarty}

Mogłoby się wydawać, że z powodu problemów etycznych zapomnieliśmy, że powinna być tu mowa o filozofii praktycznej.

Etyka i religia są dwoma rodzajami przekonań. Nie polegają one ani na znajomości szeregu twierdzeń, ani na rutynie w praktycznym działaniu, które byłoby zgodne z jakimś kodeksem etycznym, lecz są pewnymi nastawieniami umysłu.

Czym jest filozofia i czy to, co do tej pory zostało powiedziane, może nią być nazwane?

Jeżeli przez dotychczasowe rozważania choć trochę przyczyniłem się do dowartościowania religii i moralności, dokonało się to bez rozwijania pojęć i prezentacji dowodów. Próbowałem jedynie przez nieudane przedstawienie prawdy wzbudzić pewne odczucia, które i tak łatwo ulegają zmianie...

Życie wywołuje tak silne wrażenia, że nieraz wskutek porażki lub cierpienia tracimy pogodę ducha. Zniechęca nas ślepy los. Aby go przezwyciężyć, trzeba podjąć wysiłki inne niż dotychczasowe.

Filozofia jest tym, co wzmacnia aktywność i osłabia przeciwne dążenia lub je całkowicie usuwa. 
W trakcie rozważań umysł znajduje się w ciagłym i konsekwentnym napięciu, a przy tym zdobywa nowe sprawności, które zastępują los i doświadczenie.

Wyobraźnia pozwala filozofom badać istnienie aż do jego granic. Duch zdobywa wówczas określony kierunek dla swoich myśli i nie pozwala na poddanie się wątpliwościom...

Ludzie mówiący swoje tezy z energią mniejszą od mocy ich temperamentu nigdy nie zrozumieli filozofii.

Być może zapytacie, czy filozof mówi i działa słuszniej, lepiej i sprawiedliwiej?

Kto może to przewidzieć? Przecież filozofowie są też ludźmi, a czasami filozofia tych, którzy ją uprawiają zamiast umacniać ich w prawdzie, prowadzi ich do błędu. Jednak można chyba powiedzieć, że czasem oczywisty błąd bywa lepszy niż zmienne wahanie, które obserwuje się u zwyczajnych ludzi. Z pewnością świadczy to o posiadaniu charakteru w ogóle. Ale jest lepsze również dlatego, że błąd sam się zdradza na końcu i wydaje w ręce krytyki. Kto filozofuje z czystym sercem, ten zawsze pozostanie wrażliwy na taką krytykę i gotowy do przyjęcia korekty.

Badanie religijnych sposobów przedstawiania dotyczy filozofii teoretycznej lub metafizyki. Poprawianie błędów jest tu najważniejsze. Zbyt odważne stwierdzenia o religii okazują się bezpodstawne, przedmiot dyskusji zaś pozostaje sprawą sumienia. Metafizyka z kolei wyjaśnia możliwości wszelkiego poznania, charakteryzuje naturę i uzasadnia nauki matematyczne. Posługuje się spekulacją jako formą ćwiczenia ducha usprawniającą myślenie.

Uporządkowanie kwestii etycznych jest zadaniem filozofii praktycznej. Uzasadnia ona etyczne chcenie. Przed sformułowaniem celu woli umożliwia człowiekowi samodzielne rozważania, po jego zdefiniowaniu - pomaga w spełnieniu warunków do realizacji zadań. Istnieje przekonanie, że filozofii, jako wewnętrznej aktywności umysłu, nie można się nauczyć - tylko ludzie wrażliwi mogą się nią zachwycać.

Choć zasady systemu są możliwe do przyswojenia, bez odpowiedniej wiedzy nie można jasno przedstawić tez matematycznych. Praktyka w tej dyscyplinie wymaga długich ćwiczeń, ćwiczenie filozofii zaś - biegłości w stosowaniu wyrażeń i precyzji poglądów. Na początku wszystko może wydawać się niejasne, później jednak - przez doświadczenie natury i autorefleksję - uczeń uzyska klarowność pojęć filozoficznych.

W tym miejscu kończę te całkowicie niezobowiązujące odczyty. Za satysfakcjonujące uznam, jeżeli dostarczyły one wam, moi panowie, choć trochę strawy duchowej.

thum. Dariusz Stępkowski*

* Ks. dr Dariusz Stępkowski SDB, adiunkt w Instytucie Pedagogiki im. św. Jana Bosko Uniwersytetu Kardynała Stefana Wyszyńskiego w Warszawie. 